\title{
GROWTH VOLATILITY AND OPENNESS IN SUB-SAHARAN AFRICA*
}

\author{
SAHRAALTI AFRİKA’DA BÜYÜME OYNAKLIĞI VE AÇIKLIK
}

\section{Jemberu Lulie MEKONNEN** \\ A. Suut DOGRUEL ${ }^{\star * *}$}

\begin{abstract}
There is no a unique agreement regarding the impact of trade openness and financial openness on growth volatility. We carried out an empirical investigation using system GMM to assess the impact of openness on growth volatility in Sub-Saharan African. The analysis considered a panel of 29 countries from 1981 to 2010. According to our results, contrary to earlier findings, both trade and financial openness significantly reduce growth volatility in Sub-Saharan Africa. However, financial openness isn't found to be robust for different specifications. We further decomposed trade and financial openness. Trade in 'manufacturing goods' significantly reduce volatility in comparison to trade in 'nonmanufacturing goods'. A further decomposition of financial openness into FDI and portfolio flows does not reveal a significant effect on growth volatility.
\end{abstract}

Keywords: Growth Volatility; Trade Openness; Financial Openness; Sub-Saharan Africa; System GMM

JEL Classification: C33, E32, F15, F36, F41

Öz

Ticaret ve finasal açıklığının büyüme oynaklığı üzerindeki etkisi hakkında bir fikir birliği bulunmamaktadır. Bu çalışmada sistem GMM kullanılarak Sahraaltı Afrika'da açıklı̆̆ın büyüme oynaklığı üzerindeki ektisi ampirik olrak incelenmiştir. Çalışma 1981- 2010 dönemini ve 29 ülkeyi kapsamaktadır. Önceki çalışmaların tersine, elde ettiğimiz sonuçlara göre Sahraaltı Afrika'da hem ticari hem de finansal açılık büyüme oynaklığını anlamlı biçimde düşürmektedir. Ancak, farklı tanımlamalarda finansal açıklık güçlü bulunmamıştır. Bir aşama ileri giderek ticaret ve finansal açıklığı ayrıştırıldığında, imalat sektörü malları ticaretinin, imalat dışı malların ticaretine göre, oynaklığı belirgin bir biçimde azaltmaktadır. Finansal açılı̆ı̆ı doğrudan yabancı sermaye ve portfolyo akımları olarak ayrıştırmak ise büyüme oynaklığı üzerinde anlamlı bir etki göstermediği tespit edilmiştir.

Anahtar Kelimeler: Büyüme oynaklığı; Ticaret açıklığı; Finansal açılık; Sahraaltı Afrika; Sistem GMM

JEL Sınıflaması: C33, E32, F15, F36, F41

* This paper is a part of the $\mathrm{PhD}$ thesis by Jemberu L. Mekonnen under the supervision of A. S. Doğruel. Thanks to the assistance received from the Scientific and Research Council of Turkey (TUBITAK) during the PhD program.

** Kotebe Metropolitan University, Addis Ababa, Ethiopia. E-mail: jemberu21@yahoo.com

*** Marmara University, Department of Economics, Istanbul. E-mail: suut.dogruel@marmara.edu.tr 


\section{Introduction}

The positive relationship between trade openness and growth is somehow agreed on (see Frankel and Romer, 1999; Dollar, 1992). Similarly, the positive relationship between financial openness and growth is generally agreed on at least for developed countries, although still related debate continues (see Bekaert et al., 2005; Edison et al., 2002). On the other hand, the relationship between growth volatility with both trade openness and financial openness has not been studied sufficiently. The results vary from study to study. For instance, positive and negative impacts of both types of openness have been found on growth volatility. Trade openness may reduce growth volatility by making the external sector independent from domestic shocks. On the other hand, it may lead to specialization in some sectors and exposes the sector to terms of trade shocks. Financial openness may help by leading to international risk-sharing through the provision of wider financial menus but it is also prone to financial fragility and crises when finance flow to specialized sectors based on comparative advantage.

The absence of evidence of a unique relationship between growth volatility and openness and limited investigation on volatility determinants call for more research. ${ }^{3}$ According to Easterly et al. (2001: 198) "there is little empirical or theoretical work on what might determine volatility in growth rates". The paper studied trade openness and financial openness as main determinants of growth volatility. In an indirect way, Kose et al. (2006) argued that there were no studies which looked at the role of openness in the relationship between growth and volatility. Their study interacted trade and financial openness with volatility to see their impact on growth. Prasad et al. (2007) also mentioned that, compared to studies about the effect of openness on growth, its effect on growth volatility has been studied less. A similar claim was stated by Haddad et al. (2012). Recently, Caselli et al. (2015:2) called the issue an important one: "An important question at the crossroads of macro-development and international economics is whether and how openness to trade affects macroeconomic volatility". These papers tell us that even in the 2000s the determinants of growth volatility and particularly the role of trade and financial openness were not studied sufficiently when compared to studies which concentrate on the impact of openness on growth rates. Particularly for SSA, the area is a new one. For example, Ahmed and Suardi (2009: 1623) claim that, "the effect of trade and financial liberalization on the region's macroeconomic volatility, however, has never been investigated before".

Our study considers the impact of both trade and financial openness on growth volatility for Sub-Saharan Africa ${ }^{4}$. Specifically, we target addressing whether openness increases or decreases growth volatility in the region. Nowadays integration of the world trade and financial markets is increasing. Therefore, assessing openness along with domestic growth volatility is useful. Explaining volatility in relation to SSA countries may help to examine policies which may attain less volatile growth in the face of openness so as to benefit from the greater integration with world trade and financial markets which, at least theoretically, is believed to increase efficiency

3 Unless specified, openness refers to both trade openness and financial openness throughout the text.

4 SSA here after 
and competition, transfer technology and raise living standards. We hope to contribute by extending the existing studies for SSA such as Ahmed and Suardi (2009), using various measures of openness by including relevant country and macroeconomic characteristics with the help of a new data set. In the current study, 29 SSA countries are examined from 1981 to 2010 to assess the impact of trade and financial openness on growth volatility. We employ an estimation technique which can account for the possible endogeneity of the variables of interest and other regressors. For this purpose, the system GMM estimation technique is utilized here.

The paper is organized into seven sections. Following the introduction, sections two undertake a literature review. Section three specifies the model with data explanation. Section four describes the stylized facts of trade and financial openness in SSA. Estimation technique is presented in section five while the estimation results and discussion are provided in section six. Finally, section seven concludes.

\section{Literature Review}

\section{I. Debates on the Role of Openness on Growth Volatility}

\section{I.I. Trade Openness and Growth Volatility}

In general, trade openness reduces vulnerability to domestic shocks but increases external shocks (Easterly et al., 2001). The main advantage of openness in trade is that it helps growth by 'delinking' the external sector from other economic activities (Calderón et al., 2005). In this case, domestic shocks (or a decline in domestic demand) will not affect the export sector and the economy will benefit from foreign demand. Furthermore, trade naturally increases the diversification of domestic goods due to imports which increase the size of the domestic market (at the same time by lowering prices). Such market enlargement usually increases the chance of resilience. On the other hand, external shocks could affect the external sector. The argument is that trade openness dictated by external demand may lead to specialization of production which increases industry-specific external shock vulnerability (Calderón and Schmidt-Hebbel, 2008). The common example is the terms of trade problem which occurs due to primary product export specialization. Such kinds of specialization are sensitive to demand and price changes. Specialized manufacturing is also sensitive to input price and demand changes. This phenomenon is expected to increase growth volatility. However, if an economy is highly diversified, then the effects of external shocks can be minimized.

\section{I.2. Financial Openness and Growth Volatility}

The positive role of financial openness depends on increased financial access to investment. If a country has limited domestic means, financial access helps to carry out investment and increase production. According to Easterly et al. (2001), financial openness can help to meet the gap in the domestic financial services. Better financial access aids poor countries to expand 
and diversify their production base (Kose et al., 2006). This external finance helps to mitigate domestic shocks through the provision of a wider financial menu and thereby help to reduce growth volatility. Households also can smooth consumption when there are country-specific shocks through external financial means (foreign credit). Moreover, firms and consumers can minimize risk by investing in foreign portfolios. This international risk sharing mechanism is supposed to contribute towards reducing growth volatility particularly for countries with the lack of capital.

On the contrary, financial openness may lead to crises during exposure to shocks. Easterly et al. (2001: 195) put the situation as follows: "Investors observing the weakening condition of firms and financial institutions within the country in response to a shock, may decide to pull their (short-term) money out of the country and put it elsewhere, thus further weakening both firms and financial institutions (e.g. by further weakening the currency), and possibly inducing a crisis". Easterly et al. (2001) also argued that higher dependence on foreign credit by itself increases vulnerability. According to Calderón and Schmidt-Hebbel (2008), financial flows usually spent on specific sectors based on 'comparative advantage' lead to specialization, which increases the vulnerability to industry/sector specific shocks. According to Prasad and Rajan (2008), even the start of financial inflows may lead to the 'overvaluation' of the exchange rate, which may decrease the 'competitiveness' of an economy. Additionally, Prasad et al. (2007) mention a number of problems that can be associated with financial openness such as speculative attacks of domestic currency and crises due to contagion and increased government debt.

\subsection{Empirical Evidence on Openness and Growth Volatility Relationship}

Similarly, there is no common agreement on the impact of openness on growth volatility empirically. The study of Easterly et al. (2001) on the impact of both forms of openness on growth volatility in a comprehensive way is one of the 'earliest'. They consider a mixture of countries, based on the level of development, from 1960 to 1997. Their findings reveal that financial openness does not affect volatility in many cases but trade openness increases volatility. However, interaction with initial per capita GDP shows that trade openness reduces volatility for developed countries. The study stresses the role of macroeconomic structure and institutional conditions for the effect. Also, Calderón and Schmidt-Hebbel (2008) emphasize the importance of other macroeconomic characteristics in the relationship. Their study considers 82 countries from all income levels from 1975 to 2005. The results show that trade openness generally reduces growth volatility except for countries with higher production and export specialization. Equity-based financial openness reduces growth volatility and domestic financial development alleviates volatility emanating from financial openness. Kose et al. (2003) obtained mixed results on the impact of trade and financial openness on growth volatility when OLS and instrumental variable techniques were used. Trade openness was positively significant when OLS method was used. On the other hand, both trade and financial openness did not have an impact on the volatility of growth rate of 
output when instrumental variable estimation was used. The concluding remark from this study is the absence of a robust relationship between openness and volatility. Later, Kose et al. (2003) in an indirect way analyzed the relationship between growth and volatility considering the role of trade and financial openness. They found that trade integration and financial integration weakened the negative relationship between growth and volatility. Calderón et al. (2005) found that trade openness increased per capita growth rate volatility while financial openness reduced it. However, when non-linearity was considered (when the level of development increased) both were found to be volatility reducing.

Cavallo (2007) after analyzing the effect of openness on growth volatility for 77 countries, from 1960 to 2000, claimed that the stabilizing effect of trade openness on volatility outweighs the destabilizing effect. He found that although terms of trade raised output volatility, this effect was offset by a greater stabilizing effect. The financial channel was found to be working towards the stabilizing effect partly. Cavallo and Frankel (2008) considered the effect of trade openness on some specific forms of volatility (crises due to sudden stops) for 141 countries from 1970 to 2002. They found that high trade openness has a mitigating role during sudden stops (sudden cuts off in international finance). Bejan (2007) found that trade openness increased output volatility for a group of developed and developing countries from 1950 to 2000. However, the effect was found to be lower in the period 1975-2000 than in the earlier period 1950-1975. The findings indicated that higher openness increased volatility in developing countries. The study, however, when controlled for some relevant factors, obtained that trade openness reduced volatility. Recently, Haddad et al. (2012) examined the role of trade openness in explaining growth volatility by considering product and market diversification for a group of developed and developing countries. Their study documented a significant reduction of volatility for economies highly diversified in terms of exports. The result was more pronounced for developing countries. For the role of market diversification, they found mixed results. When they looked at only the relationship between trade openness and growth volatility, they found a negative but an insignificant result using the system GMM method. Specifically to financial openness, the findings of Buch et al. reveal that the relationship between financial openness and business cycle volatility is not a clear one. While it had a significant effect in the 90s, it did not have any effect in the 70s and 80s. Bekaert et al. (2006) studied the impact of equity market liberalization on consumption and GDP growth volatility. Accordingly, consumption growth volatility significantly declined and they did not find any rising evidence for GDP growth volatility.

Kim (2007) distinguished between external risk and economic openness. The former refers to "the stability of terms and conditions under which a given economy trades with foreign economies" and the latter refers to "the exposure to the international economy" (Kim, 2007: 182). The study postulates that economic openness may not necessarily lead to increasing volatility as it depends on the structure of economies and diversification. But external risk will likely increase economic volatility. The result for 175 countries from 1950 to 2002 was consistent with the postulation: higher effect of external risk on volatility but less support for openness. Similarly, Caselli et al. (2015) distinguished sector- and country-specific shocks after considering the existing argument 
on the volatility-increasing role of trade openness. According to their assessment, trade openness could reduce growth volatility if the main source of shock comes from the country-specific one. At firm level, Buch et al. (2009) findings using Germany's firm level data revealed that trade openness impact on firm-level volatility was ambiguous. Similarly, di Giovanni and Levchenko (2009: 558) examined the relationship between volatility and trade at an industry level. The main results were presented as follows: "First, sectors more open to international trade are more volatile. Second, more trade in a sector is accompanied by a lower correlation between growth in that sector and aggregate growth, an effect that leads to a reduction in aggregate volatility, all else equal. Third, countries that are more open exhibit greater specialization, which works as a channel for creating increased volatility.

When we consider SSA specifically, there are few and fragmented studies about growth volatility and openness nexus. For example, Kose and Riezman (1999) focused on how external shocks in Africa explained macroeconomic fluctuations using theoretical models. Bleaney and Greenaway (2001) assessed the impact of terms of trade and exchange rate volatility on growth volatility. Sissoko and Dibooglu (2006) focused on the exchange rate system and its relation to macroeconomic fluctuations. Ahmed and Suardi (2009), however, specifically looked at the impact of both trade and financial openness on growth volatility for SSA from 1971-2005. Their findings show that trade openness increases volatility and financial openness reduces growth volatility.

\section{Model and Data}

The model specified here is based on Easterly et al. (2001), Kose et al. (2003), Calderón and Schmidt-Hebbel (2008), and Haddad et al. (2012), among others. Specifically to SSA, we extend Ahmed and Suardi's (2009) model using different measures of openness and a recent data set.

The baseline regression equation to be estimated is as follows:

$$
\sigma\left(\mathrm{dy}_{\mathrm{it}}\right)=\mathrm{a}_{\mathrm{i}}+\mathrm{O}_{\mathrm{it}} \Omega+\mathrm{X}_{\mathrm{it}} \theta+\varepsilon_{\mathrm{it}}
$$

where, $\sigma\left(\mathrm{dy}_{\mathrm{it}}\right)$ is growth volatility measured as the standard deviation of the log difference of per capita GDP, $\mathrm{O}_{\mathrm{it}}$ is the matrix of openness variables, $\Omega$ is the vector of openness coefficient, $\mathrm{X}_{\mathrm{it}}$ is a matrix of control variables, $\theta$ is a vector of coefficients for control variables, $\alpha_{\mathrm{i}}$ represents country fixed effects, $\varepsilon_{\mathrm{it}}$ is the error term, $i$ shows countries and $t$ is time in years. We have an unbalanced panel of 29 SSA countries from 1981 to 2010. ${ }^{5}$ All data are taken as 5 year-averages. The standard 5 years (non-overlapping) averaging technique is quite common. Its advantage is to suppress the cyclical fluctuations/noise in the data which otherwise could exist over a long time. We use per capita GDP growth volatility instead of per capita GDP or GDP volatility. The advantage of growth than level volatility is that policy makers target in getting stable growth rather than output level (Haddad et al., 2012). 
Openness includes both trade and financial openness. Both are measured based on de facto and de jure methods. While the former is based on the existence of restrictions on the trade and financial flows, the latter considers the actual volume of trade and financial flows. The de facto measure of trade openness is the log of total trade as a percentage of GDP and the financial openness measure is the ratio of the sum of the stock of portfolio equity and FDI assets and liabilities to GDP. The de jure measures are the official trade and external financial liberalization dates. The control variables included are the following: per capita GDP, financial development, fiscal policy volatility, terms of trade volatility, inflation volatility, and natural disasters. We do not include some other factors in the model and the time period beyond 2010 mainly due to data limitation. We prefer Lane and Milesi-Ferretti (2007)'s data to measure financial flows since stock variables are not influenced by year to year changes and less affected by measurement error, Prasad et al. (2007), Baltagi, et al. (2009). We further decompose trade flows into 'trade in manufacturing goods' and 'trade in non-manufacturing goods'. We take only merchandised trade. Similarly, we decompose financial flows into FDI and portfolio equity flows to analyze the role of each flow. ${ }^{6}$

\section{Descriptive Statistics}

Figure 1 shows the unconditional relationship of growth volatility with trade and financial flows. ${ }^{7}$ Since we have found Mauritius to be an outlier in financial flows, we draw the plot with (panel $\mathrm{A}$ and $\mathrm{B}$ ) and without (panel C and D) the outlier. The scatter plot shows the average values of trade and financial flows in relation to growth volatility. All of the panels reveal a clear negative relationship of growth volatility with both trade and financial flows. Even the removal of the outlier in the financial flows did not change the negative relationship very much. However, to tell the precise relationship, we need to estimate controlled regressions which consider other factors that can affect volatility.

6 See Appendix 2 for data construction techniques and sources for all variables

7 Trade and financial flows alternatively used with trade and financial openness. 


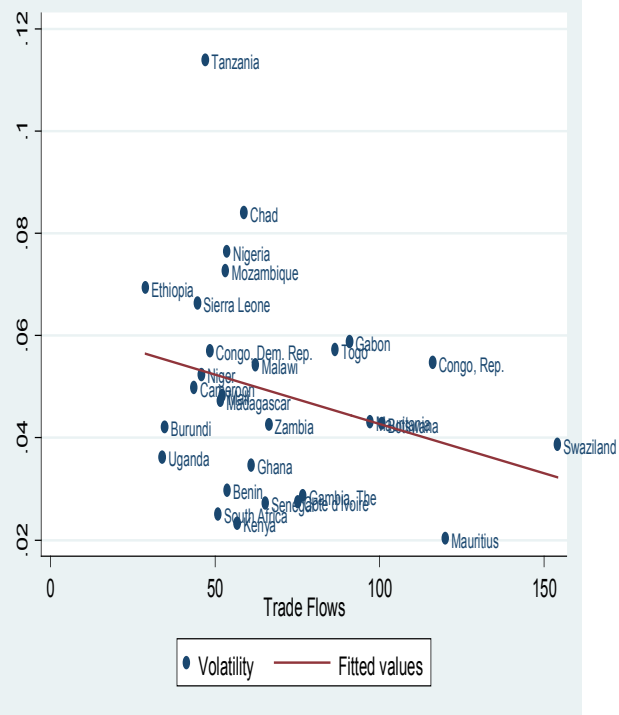

(A)

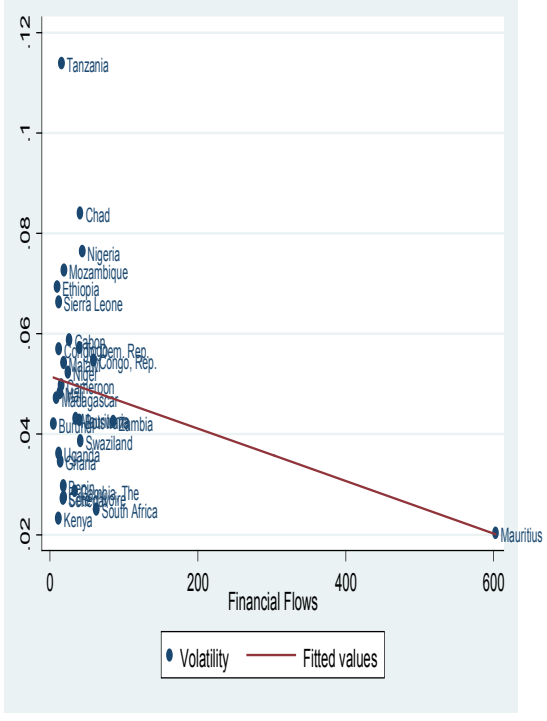

(B)

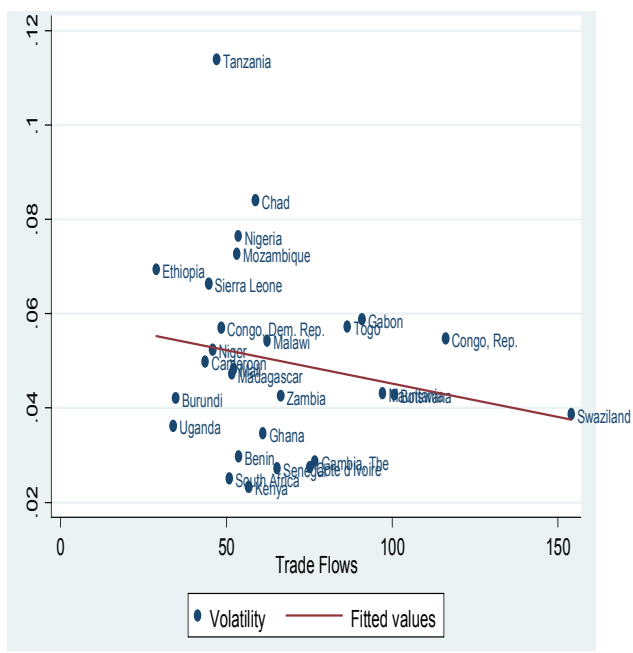

(C)

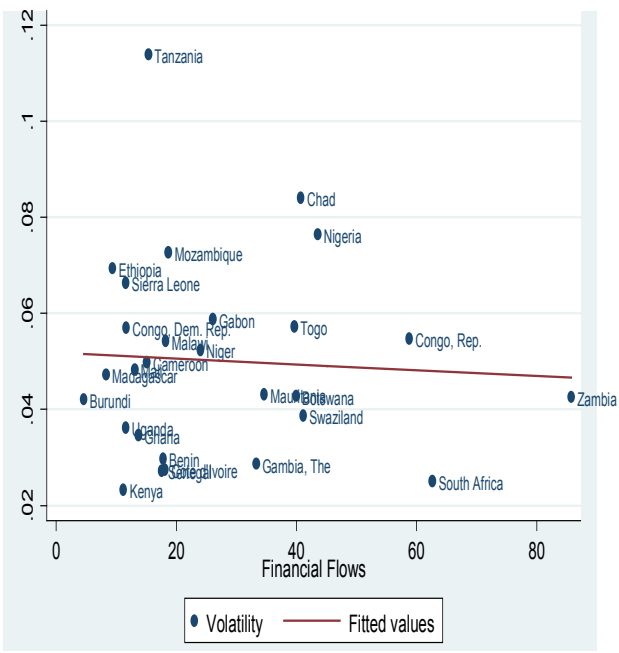

(D)

Figure I: Growth Volatility, Trade, and Financial Flows

Source: Author's calculation.

Notes: Horizontal axis shows average trade and financial flows as a percentage of GDP from 1981 to 2010. The vertical axis shows growth volatility measured as the standard deviation of the log difference of per capita GDP for the same period. 
Figure 2 plots growth volatility with trade and financial flows as well as with their components from 1986 to 2010 in panels A, B, C and D. As in Figure 1, the last two panels (C and D) are drawn without Mauritius. First of all, volatility showed a declining trend throughout the period. Declining volatility has been documented in some studies; see, for example, Kose et al. (2003) and Blanchard and Simon (2001). In panel A, trade flows showed a rising trend. It rose from $62 \%$ in 1986 to $74 \%$ of GDP in 2010. A steady rise is observed after 1999. Approximately, both 'trade in manufacturing' and 'non-manufacturing goods' swing between $20 \%$ and $30 \%$ of GDP throughout the period. Panel C reveals somehow similar information with panel A. In panel B, financial flows show a steady increment from year to year. It rose from $17 \%$ in 1986 to $246 \%$ of GDP in 2010 . Since there are very high financial inflows to Mauritius in recent periods, the average value is seriously affected. For this reason, we consider a graph without Mauritius in panel D. The steady growth in financial flows is preserved in this panel as well. FDI flows are the largest. Portfolio equity flows, on the other hand, are smaller with a significant rise in the recent period. Until 1997, it did not reach to even $1 \%$ level. The panels also show that both trade and financial flows affected by the recent financial crisis.

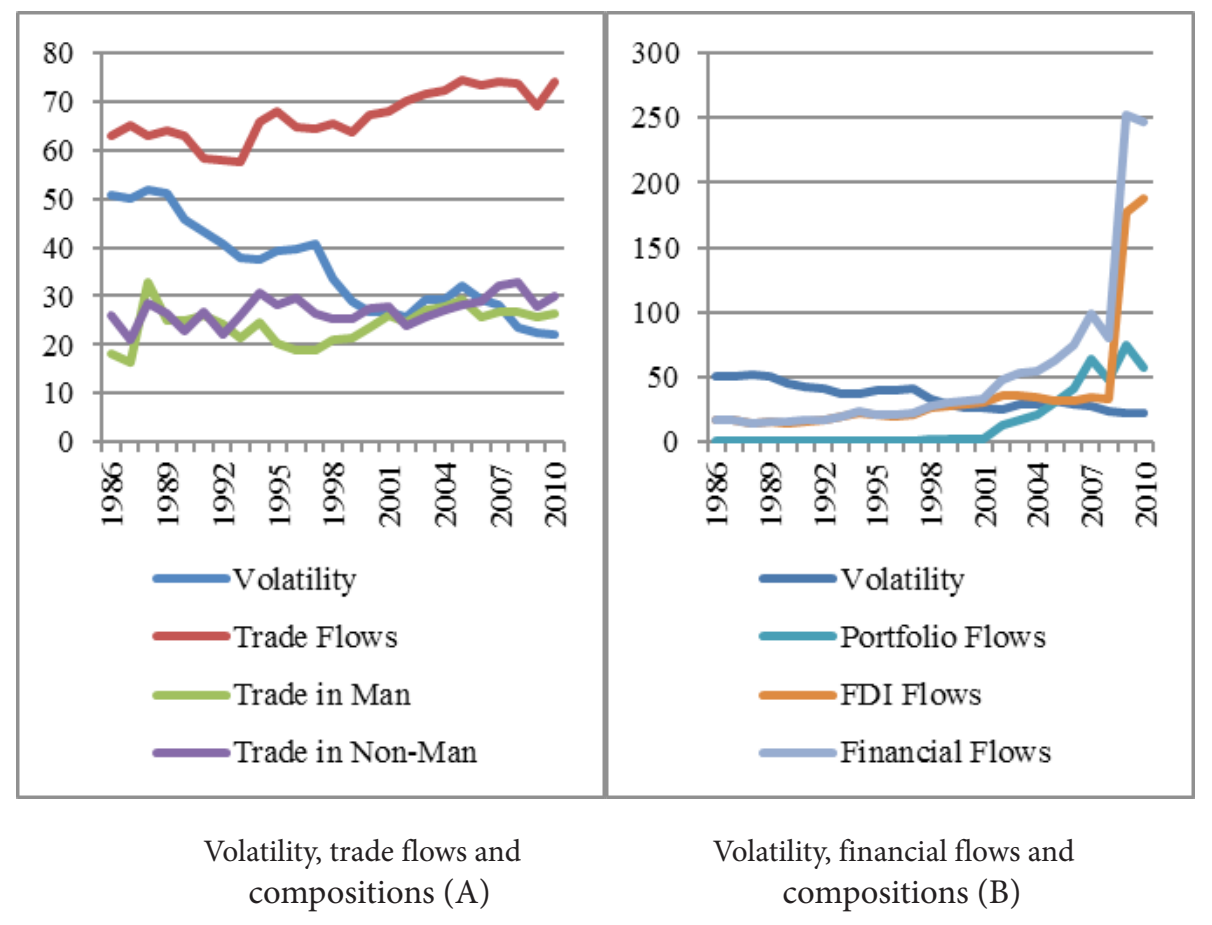




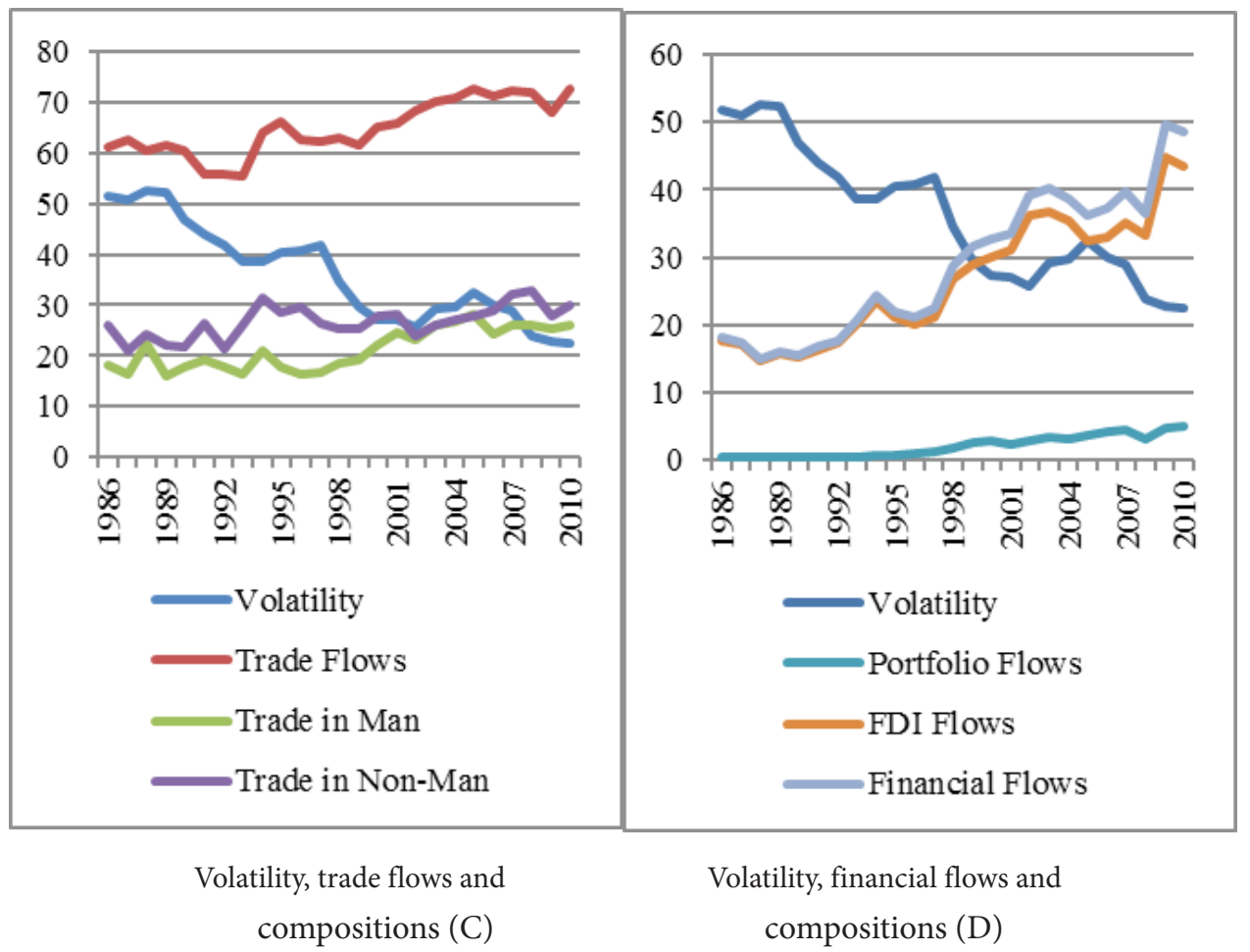

Figure 2: Growth Volatility, Trade, and Financial Flows with their Compositions

Source: Author's calculation.

Notes: All variables, except volatility, are in \% of GDP. The value for each year is the average value of all countries considered in the study. Volatility, on the vertical axis, is the standard deviation of the log difference of per capita GDP. We use 5 years rolling windows to calculate growth volatility. In such a way, growth volatility for 1986 is the standard deviation of the growth rate from 1981 to 1985 , and so on. It is multiplied by 1000 to bring it up to the same scale.

\section{Estimation Technique}

System GMM method of estimation is used to handle possible endogeneity problems of our variables of interest and other regressors. Endogeneity could arise due to omitted variables or simultaneity (when a regressor is determined together with the dependent variable). GMM handles both sorts of problems and also controls for time-invariant country-specific effects. The method is also suitable for larger panels and shorter time periods.

We preferred Arellano and Bover (1995) and Blundell and Bond (1998) system GMM over Arellano and Bond (1991) difference GMM. Arellano and Bond (1991) apply first differences 
to transform the equation. ${ }^{8}$ This differencing removes country specific effects, makes righthand side variables stationary and eliminates the endogeneity that may arise due to fixed effects and explanatory variables correlation (Baltagi et al., 2009: 287). However, when variables are close to random walk, the lagged levels will be poor instruments for the transformed variables (Roodman, 2009). Arellano and Bover (1995) and Blundell and Bond (1998) developed the system GMM, which produces an efficient estimator by combining specification both in levels and first differences, which helps to minimize the weak instrument problem. Lagged values of endogenous regressors are used as instruments for the endogenous variables. The endogenous variables used in the estimation are: lagged growth volatility, per capita GDP, financial development, and trade. Endogeneity of trade is according to Rodríguez and Rodrik (2001). Cavallo and Frankel (2008) also, consider the endogeneity of trade because it is the result of overall reform. Per capita GDP and level of financial development are also assumed to be endogenous in many empirical studies due to their strong tie with the level of development which leads to simultaneity.

\section{Estimation Results and Discussion}

Our estimation results are consistent for the validity of system GMM. In all of our results, Hansen test of overidentifying restrictions is valid. We cannot reject the null hypothesis as confirmed by high $p$ values. Thus, instruments are valid. According to AR (1) and AR (2) test results, the absence of first and second order serial correlation null is rejected for the first order and is not rejected for the second order. Therefore, we can keep analyzing our results. Our estimation results are presented in Table 1,2 and 3. Column 1 and 3 are based on per capita GDP growth volatility measure and column 2 and 4 in all tables are based on GDP growth volatility which we included for robustness check. It is calculated as the log difference of GDP (constant 2005 US\$).

We will mainly consider the estimation with the de facto measures of trade and financial openness. As we explained earlier, the reason behind this is that de facto measures are based on the actual volume of flows. However, we will begin with the de jure measures. As presented in Table 1, trade liberalization has a positive and significant effect on growth volatility. Financial liberalization measure has a negative but an insignificant effect. Both measures capture the effect on growth volatility after the trade and external finance are officially liberalized. Based on our results, growth volatility increases after trade liberalization. On the other hand, growth volatility is not significantly affected after financial liberalization. The simple inference implies that trade liberalization increases volatility. As discussed in the literature review, an increase in volatility can be possible if a more liberalized trade is accompanied by greater external shocks.

8 See Arellano and Bond (1991), Arellano and Bover (1995) and Blundell and Bond (1998) for the complete econometric procedure; and Roodman (2009) for the detailed estimation procedure using the xtabond2 command in STATA. 
Table I: Growth Volatility and De Jure Measures of Openness

\begin{tabular}{|l|l|l|}
\hline Variables & $(\mathbf{1})$ & $\mathbf{( 2 )}$ \\
\hline Growth Volatility (lag) & $-0.079(-0.40)$ & $-0.049(-0.24)$ \\
\hline Per Capita GDP & $0.0042(0.73)$ & $0.004(0.76)$ \\
\hline Fiscal Policy Volatility & $0.084(2.06)^{* \star}$ & $0.078(1.67)$ \\
\hline Natural Disaster & $0.128(2.26)^{* \star}$ & $0.132(2.33)^{* \star}$ \\
\hline Financial Development & $-0.005(-0.39)$ & $-0.006(-0.50)$ \\
\hline Terms of Trade Volatility & $0.043(1.50)$ & $0.045(1.22)$ \\
\hline Inflation Volatility & $0.072(0.75)$ & $0.092(0.86)$ \\
\hline Trade Liberalization & $0.0014(4.21)^{* * *}$ & $0.001(3.84)^{* * *}$ \\
\hline Financial Liberalization & $-0.010(-0.78)$ & $-0.007(-0.51)$ \\
\hline No. of countries/observations & $22 / 99$ & $22 / 99$ \\
\hline AR(1) & $-1.72(0.085)^{\star}$ & $-1.76(0.079)^{\star}$ \\
\hline AR(2) & $-0.67(0.505)$ & $-0.53(0.593)$ \\
\hline Hansen - p value & 0.789 & 0.642 \\
\hline
\end{tabular}

Notes: ${ }^{* *} / * * / *$ shows significance at $1 \% / 5 \% / 10 \%$ level respectively. We allowed robust standard errors/correct for heteroscedasticity. The $t$ statistics are in parentheses. No constant in the regression. Use of too many instruments may create problems. 'There is convincing evidence that too many moment conditions introduce bias while increasing efficiency' (Baltagi et al., 2009: 288). For this reason, we use a maximum lag of two by using collapse lag (2 2) in the xtabond 2 syntaxes of Roodman (2009). In addition to the three variables we mentioned, financial liberalization is considered as endogenous in this regression.

Our main results are presented in Table 2. Since restrictions on trade and finance may not capture all the impact, we consider the real flows as the main measures. According to our results, both trade and financial openness have a significant negative effect on growth volatility. Hence, both are playing a growth volatility minimizing role in SSA. We may question why volatility is increasing based on the de jure measure but not based on the de facto measure of trade openness. There may be two explanations. First, they do not measure the same thing. The results of de jure based methods should not be used as substitutes for de facto measures. The former shows restrictions of flows but the latter measure shows the actual flows. Prasad et al. (2007) comment on the interpretation of de jure and de facto measures of openness. According to them, in de jure measures, the difficulties arise from the diverse nature of flow control and different levels of implementation for the controls among countries. On the other hand, actual flows cannot be easily regulated. That is, while some countries are relatively closed based on de jure classification, they may be open in terms of the de facto measure, and vice versa. Second, an increase of an external shock due to trade does not necessarily lead to higher growth volatility. Terms of trade shocks may increase volatility, but the volume of flow may not increase volatility. For example, Kim (2007) finds that external risk due to trade increases volatility while actual flows are not found to be increasing volatility.

In general, the negative effect of trade and financial openness on growth volatility is in contrast to some studies for developing countries. Particularly for trade openness, the majority of earlier 
studies documented a volatility increasing role. Our de facto based result does not support this evidence. This could be because volatility may increase during the initial process of trade openness and then at a later stage it may decrease. At this stage perhaps trade is playing a volatility reducing role. A similar analogy for financial openness can be assumed. Moreover, increasing institutional reforms, compared to earlier periods, may have helped SSA countries to be more shock resilient. Relative improvements in infrastructure, better macro policies, and labor and product market flexibility may have helped to benefit more from openness. Earlier, it was believed that even smaller shocks abroad disproportionally affect SSA countries.

We have included some main determinants of growth volatility using the relevant literature. As mentioned earlier, other countries and macroeconomic characteristics play a crucial role in shaping the relationship between openness and growth volatility. Accounting for these factors help to gauge the 'true' effect of openness on volatility. We have found some interesting effects of these factors on growth volatility. We use per capita GDP to account for country size and level of development. As the level of development is increasing, growth volatility is supposed to decline. The higher the per capita GDP, the higher the diversification in trade and financial flows assumed. Therefore, we expect a negative result. Nevertheless, in our main results, it is positive and significant. It is at odds with theoretical expectations. However, when we check the mix of countries, we detect something which can be a clue for the result. Most of the countries with higher per capita GDP are also 'resource rich' countries. These countries tend to have higher growth volatility. Higher growth volatility with higher per capita GDP may have been obtained due to this reason.

Fiscal policy volatility which only captures the discretionary part is expected to contribute positively to growth volatility. Discretionary fiscal policy shows changes in government consumption due to exogenous policy changes (intentional action to raise or reduce government expenditure) rather than a policy which considers the state of an economy, Calderón and Schmidt-Hebbel (2008). We have found a positive and significant effect of discretionary fiscal policy volatility on growth volatility. This is in line with theoretical justifications and empirical findings. Loayza et al. (2007) mention that 'erratic fiscal policy' could trigger economic volatility. This form of policy is usually used in developing countries. Empirically, Fata's and Mihov (2003; 2013) document such a positive role.

One of the most important variables to capture the external shock effect is the terms of trade. We have found a strong positive impact of terms of trade volatility on growth volatility in Table 2. For developing countries, terms of trade changes - particularly fluctuations in export goods prices - have been considered as the main source of shocks. Calderón et al. (2005: 5) say that "for truly small countries (those facing infinite demand/supply elasticity for their exports/imports of capital and goods), only price variables matter for determining domestic performance, including growth". Kose (2002) claims that price shocks explain around 88\% of aggregate output fluctuations in developing countries. Specifically for SSA, Bleaney and Greenaway (2001) also, confirm the role of terms of trade shocks in causing output fluctuations. 
The natural disaster variable has a positive and significant role in explaining growth volatility in SSA. We expected a minimum role of natural disaster. However, it turns out to be significant and strong factor. In relation to this, Raddatz (2007) notes that natural disasters may have a small role in explaining output fluctuations in low-income countries but their effect is 'economically meaningful'. In our finding, it has a high explanatory power. For financial development, we do not find a unique effect. Even though it is insignificant with a negative coefficient in Table 2, it has a positive and significant effect in Table 3, columns 1 and 3. The direction of the effect is not clear from our analysis. The effect of inflation volatility on growth volatility failed to be significant although a significant positive effect was expected. Inflation is related to uncertainty. The higher the inflation, the higher the uncertainty expected. Uncertainty, in turn, may increase volatility. Most importantly, higher inflation volatility is usually the manifestation of bad economic performance which can be positively linked to volatility.

Table 2: Growth Volatility and De Facto Measures of Openness

\begin{tabular}{|l|l|l|}
\hline Variables & $(\mathbf{1})$ & $(2)$ \\
\hline Growth Volatility (lag) & $0.175(1.28)$ & $0.172(1.34)$ \\
\hline Per Capita GDP & $0.021(2.21)^{* *}$ & $0.019(2.05)^{* *}$ \\
\hline Fiscal Policy Volatility & $0.108(1.97)^{\star}$ & $0.109(2.09)^{* *}$ \\
\hline Natural Disaster & $0.217(2.31)^{* *}$ & $0.212(2.24)^{* *}$ \\
\hline Financial Development & $-0.003(-0.38)$ & $-0.004(-0.49)$ \\
\hline Terms of Trade Volatility & $0.065(2.85)^{* * *}$ & $0.066(3.05)^{* * *}$ \\
\hline Inflation Volatility & $0.020(0.49)$ & $0.019(0.48)$ \\
\hline Trade Flows & $-0.033(-2.20)^{* *}$ & $-0.028(-1.93)^{\star}$ \\
\hline Financial Flows & $-0.0006(-2.00)^{\star}$ & $-0.0004(-1.60)$ \\
\hline No. of countries/observations & $29 / 128$ & $29 / 128$ \\
\hline AR(1) & $-2.01(0.045)^{* *}$ & $-2.04(0.041)^{* *}$ \\
\hline AR(2) & $0.22(0.822)$ & $0.24(0.811)$ \\
\hline Hansen $-\mathrm{p}$ value & 0.867 & 0.936 \\
\hline
\end{tabular}

Notes: See notes for the Table 1.

The effect of openness on growth volatility depends on the composition of trade and financial flows. Trade is getting more diversified than earlier periods. Equity related flows are also increasing for SSA countries. We consider the role of trade in 'manufacturing goods' and trade in 'non-manufacturing goods' on growth volatility. We can think of this form of trade classification as a crude measure of diversification which can show vulnerability. Similarly, we split financial flows into portfolio equity and FDI flows. The results are presented in Table 3 . As expected, trade in 'manufacturing goods' is found to be reducing volatility significantly than trade in 'non-manufacturing good. The logic behind it is that 'non-manufacturing goods' are 
particularly vulnerable to price changes and an increase in manufactured goods through diversification can help to reduce vulnerability. Decomposition of financial flows into FDI and portfolio flows does not reveal a significant effect on growth volatility. The role of individual flows seems yet to be realized.

Table 3: Growth Volatility and De Facto Measures of Openness with their Components

\begin{tabular}{|c|c|c|c|c|}
\hline Variables & (1) & (2) & (3) & (4) \\
\hline $\begin{array}{l}\text { Growth Volatility } \\
\text { (lag) }\end{array}$ & $\begin{array}{l}0.012 \\
(0.11) \\
\end{array}$ & $\begin{array}{l}0.170 \\
(1.24) \\
\end{array}$ & $\begin{array}{l}0.041 \\
(0.29) \\
\end{array}$ & $\begin{array}{l}0.168 \\
(1.29) \\
\end{array}$ \\
\hline Per Capita GDP & $\begin{array}{c}0.017 \\
(1.73)^{*}\end{array}$ & $\begin{array}{c}0.021 \\
(2.21)^{* *}\end{array}$ & $\begin{array}{l}0.012 \\
(1.10)\end{array}$ & $\begin{array}{c}0.019 \\
(2.04)^{\star *}\end{array}$ \\
\hline Fiscal Policy Volatility & $\begin{array}{c}0.111 \\
(2.52)^{\star *}\end{array}$ & $\begin{array}{c}0.105 \\
(1.93)^{*}\end{array}$ & $\begin{array}{c}0.102 \\
(2.35)^{\star *}\end{array}$ & $\begin{array}{c}0.107 \\
(2.07)^{\star *}\end{array}$ \\
\hline Natural Disaster & $\begin{array}{c}0.190 \\
(1.88)^{\star}\end{array}$ & $\begin{array}{c}0.218 \\
(2.28)^{\star *}\end{array}$ & $\begin{array}{c}0.169 \\
(1.71)^{\star}\end{array}$ & $\begin{array}{c}0.212 \\
(2.21)^{\star *}\end{array}$ \\
\hline Financial Development & $\begin{array}{c}0.013 \\
(1.98)^{*} \\
\end{array}$ & $\begin{array}{l}-0.003 \\
(-0.34) \\
\end{array}$ & $\begin{array}{c}0.012 \\
(1.85)^{*} \\
\end{array}$ & $\begin{array}{l}-0.003 \\
(-0.44) \\
\end{array}$ \\
\hline $\begin{array}{l}\text { Terms of Trade } \\
\text { Volatility }\end{array}$ & $\begin{array}{c}0.044 \\
(2.72)^{\star *}\end{array}$ & $\begin{array}{c}0.063 \\
(2.77)^{\star * *}\end{array}$ & $\begin{array}{c}0.043 \\
(2.86)^{* * *}\end{array}$ & $\begin{array}{c}0.064 \\
(3.00)^{* * *}\end{array}$ \\
\hline Inflation Volatility & $\begin{array}{l}0.036 \\
(0.46)\end{array}$ & $\begin{array}{l}0.021 \\
(0.50)\end{array}$ & $\begin{array}{l}0.028 \\
(0.42) \\
\end{array}$ & $\begin{array}{l}0.020 \\
(0.50)\end{array}$ \\
\hline Trade Flows & & $\begin{array}{c}-0.033 \\
(-2.18)^{\star *}\end{array}$ & & $\begin{array}{c}-0.028 \\
(-1.92)^{\star}\end{array}$ \\
\hline Financial Flows & $\begin{array}{c}-0.001 \\
(-3.26)^{\star * *}\end{array}$ & & $\begin{array}{l}-0.0009 \\
(-2.38)^{* *}\end{array}$ & \\
\hline $\begin{array}{l}\text { Trade in } \\
\text { Manufacturing goods }\end{array}$ & $\begin{array}{c}-0.031 \\
(-2.49)^{* *}\end{array}$ & & $\begin{array}{c}-0.027 \\
(-2.02)^{* *}\end{array}$ & \\
\hline $\begin{array}{l}\text { Trade in Non- } \\
\text { manufacturing goods }\end{array}$ & $\begin{array}{l}-0.015 \\
(-1.32) \\
\end{array}$ & & $\begin{array}{l}-0.008 \\
(-0.62) \\
\end{array}$ & \\
\hline Portfolio Flows & & $\begin{array}{l}-0.003 \\
(-0.98)\end{array}$ & & $\begin{array}{l}-0.002 \\
(-0.79)\end{array}$ \\
\hline FDI Flows & & $\begin{array}{l}0.001 \\
(0.60) \\
\end{array}$ & & $\begin{array}{l}0.001 \\
(0.50) \\
\end{array}$ \\
\hline $\begin{array}{l}\begin{array}{l}\text { No. of countries/ } \\
\text { observations }\end{array} \\
\end{array}$ & $26 / 100$ & $29 / 128$ & $26 / 100$ & $29 / 128$ \\
\hline $\operatorname{AR}(1)$ & $\begin{array}{c}-1.85 \\
(0.064)^{\star}\end{array}$ & $\begin{array}{c}-1.98 \\
(0.048)^{* *}\end{array}$ & $\begin{array}{c}-1.82 \\
(0.068)^{\star}\end{array}$ & $\begin{array}{c}-2.02 \\
(0.043)^{* *}\end{array}$ \\
\hline $\operatorname{AR}(2)$ & $\begin{array}{c}-1.16 \\
(0.248) \\
\end{array}$ & $\begin{array}{c}0.19 \\
(0.846) \\
\end{array}$ & $\begin{array}{c}-0.97 \\
(0.330) \\
\end{array}$ & $\begin{array}{c}0.22 \\
(0.831)\end{array}$ \\
\hline Hansen - p value & 0.830 & 0.832 & 0.949 & 0.920 \\
\hline
\end{tabular}

Notes: See notes for the Table 1. In addition to the three variables we mentioned, inflation volatility is considered as endogenous in columns 1 and 3.

Main model, model with de facto measure of openness, is estimated again to see the effect of financial flows on openness when the outlier is removed. Results are presented in Table 4. In 
this case, financial openness failed to be significant. As far as financial flows are concerned, it seems that the results aren't robust. Apart from the positive and negative argument on its effect on volatility, there are other explanations for non-robust results. Openness effect may be different based on levels of development: may have non-monotonic effect. Three stages may be observed: at the beginning increasing, at the middle neutral, at a later stage decreasing effect. A robust decline in growth volatility due to financial openness may not be observed without moving to the third stage. Another argument says that in order to have a benefit from openness, the (long run) benefit should exceed the (short run) cost. According to Prasad and Rajan (2008) the benefit may not be observed in regression due to some reasons. First, at the lower level of institutional development, the benefit may not exceed the cost. Second, the capital flow's institutional improving behavior (called 'collateral benefit') is low at lower level of development. Third, capital openness measures may not accurately capture the effect.

Table 4: Growth Volatility and De Facto Measures of Openness - without Mauritius

\begin{tabular}{|l|l|l|}
\hline Variables & $\mathbf{( 1 )}$ & $\mathbf{( 2 )}$ \\
\hline Growth Volatility (lag) & $0.153(1.27)$ & $0.163(1.36)$ \\
\hline Per Capita GDP & $0.020(2.23)^{\star *}$ & $0.019(2.09)^{\star *}$ \\
\hline Fiscal Policy Volatility & $0.079(1.31)$ & $0.089(1.44)$ \\
\hline Natural Disaster & $0.193(1.96)^{\star}$ & $0.199(2.06)^{\star *}$ \\
\hline Financial Development & $-0.003(-0.43)$ & $-0.004(-0.52)$ \\
\hline Terms of Trade Volatility & $0.060(2.47)^{\star *}$ & $0.062(2.68)^{\star *}$ \\
\hline Inflation Volatility & $0.018(0.57)$ & $0.017(0.52)$ \\
\hline Trade Flows & $-0.028(-2.05)^{\star *}$ & $-0.026(-1.89)^{\star}$ \\
\hline Financial Flows & $-0.014(-0.79)$ & $-0.009(-0.50)$ \\
\hline No. of countries/observations & $28 / 123$ & $28 / 123$ \\
\hline AR(1) & $-1.99(0.046)^{\star *}$ & $-2.03(0.042)^{\star *}$ \\
\hline AR(2) & $0.36(0.718)$ & $0.34(0.732)$ \\
\hline Hansen - p value & 0.950 & 0.964 \\
\hline
\end{tabular}

Notes: See notes for the Table 1.

\section{Conclusion}

In contrast to some previous studies, we have found that both trade and financial openness reduce growth volatility in SSA. Our results are robust to the choice of the dependent variable but not to the choice of countries and independent variables. In this regard, financial openness is found to be sensitive to country changes. 'Trade in manufacturing goods' is found to be significantly reducing volatility in comparison to 'trade in non-manufacturing goods'. A further decomposition of financial openness into FDI and portfolio equity flows has not provided a significant effect on growth volatility. From these results, we can conclude that SSA countries are benefiting from greater openness through a decrease in growth volatility. This can be thought as a crucial benefit since for most developing countries high growth volatility tends to reduce growth rate. 


\section{References}

Ahmed, A. D., and Suardi, S. (2009). Macroeconomic Volatility, Trade and Financial Liberalization in Africa. World Development, 37 (10): 1623-1636.

Arellano, M., and Bond, S. (1991). Some Tests of Specification for Panel Data: Monte Carlo Evidence and An Application to Employment Equations. Review of Economic Studies, 58: 277-297.

Arellano, M., and Bover, O. (1995). Another Look at The Instrumental-Variable Estimation of ErrorComponents Models. Journal of Econometrics, 68: 29-51.

Baltagi, B. H., Demetriades, P. O., and Law, S. H. (2009). Financial Development and Openness: Evidence from Panel Data. Journal of Development Economics, 89: 285-296.

Bejan, M. (2007). Trade Openness and Output Volatility. MPRA, Paper No. 2759.

Bekaert, G., Harvey, C. R., and Lundblad, C. (2005). Does Financial Liberalization Spur Growth?. Journal of Financial Economics, 77: 3-55.

Bekaert, G., Harvey, C. R., and Lundblad, C. (2006). Growth Volatility and Financial Liberalization. Journal of International Money and Finance, 25: 370-403.

Blanchard, O. J., and Simon, J. A. (2001). The Long and Large Decline in U.S. Output Volatility. Brookings Papers on Economic Activity: 135-174.

Bleaney, M. and Greenaway, D. (2001). The Impact of Terms of Trade and Real Exchange Rate Volatility on Investment and Growth in Sub-Saharan Africa. Journal of Development Economics, 65 (2): 491-500.

Blundell, R., and Bond, S. (1998). Initial Conditions and Moment Restrictions in Dynamic Panel Data Models. Journal of Econometrics, 87: 115-43.

Buch, C. M., Doepke, J., and Pierdzioch, C. (2005). Financial Openness and Business Cycle Volatility. Journal of International Money and Finance, 24: 744-765.

Buch, C. M., Döpke, J., and Strotmann, H. (2009). Does Export Openness Increase Firm-Level Output Volatility?. The World Economy, 32 (4): 531-551.

Calderón, C., and Schmidt-Hebbel, K. (2008). Openness and Growth Volatility. Central Bank of Chile Working Papers, 483.

Calderón, C., Loayza, N., and Schmidt-Hebbel, K. (2005). Does Openness Imply Greater Exposure?. World Bank Policy Research Working Paper, 3733.

Caselli, F., Koren, M., Lisicky, M., and Tenreyro, S. (2015). Diversification Through Trade. NBER Working Paper, 21498.

Cavallo, E. A. (2007). Output Volatility and Openness to Trade: A Reassessment. Inter-American Development Bank Working Paper, 604.

Cavallo, E. A., and Frankel, J. A. (2008). Does Openness to Trade Make Countries More Vulnerable to Sudden Stops, Or Less? Using Gravity to Establish Causality. Journal of International Money and Finance, 27: 1430-1452.

Di Giovanni, J., and Levchenko, A. A. (2009). Trade Openness and Volatility. The Review of Economics and Statistics, 91 (3): 558-585.

Dollar, D. (1992). Outward-Oriented Developing Economies Really Do Grow More Rapidly: Evidence from 95 LDCs, 1976-85. Economic Development and Cultural Change, 40 (3): 523-544.

Easterly, W., Islam, R., and Stiglitz, J. E. (2001). Shaken and Stirred: Explaining Growth Volatility. Annual Bank Conference on Development Economics, Eds: B. Pleskovic and N. Stern, Washington, DC, The World Bank: 191-211. 
Edison, H. J., Levine, R., Ricci, L., and Sløk, T. (2002). International Financial Integration and Economic Growth. Journal of International Money and Finance, 21: 749-776.

Fata'S, A., and Mihov, I. (2003). The Case for Restricting Fiscal Policy Discretion. Quarterly Journal of Economics, 118 (4): 1419-1447.

Fata'S, A., and Mihov, I. (2013). Policy Volatility, Institutions, and Economic Growth. Review of Economics and Statistics, 95 (2): 362-376.

Frankel, J. A., and Romer, D. (1999). Does Trade Cause Growth?. American Economic Review, 89: 379- 399.

Haddad, M., Lim, J. J., Pancaro, C., and Saborowski, C. (2012). Trade Openness Reduces Growth Volatility When Countries are Well Diversified. European Central Bank Working Paper Series, 1491.

Kim, S. Y. (2007). Openness, External Risk, and Volatility: Implications for The Compensation Hypothesis. International Organization, 61 (1): 181-216.

Kose, M.A. (2002). Explaining Business Cycles in Small Open Economies: How Much Do World Prices Matter?. Journal of International Economics, 56: 299-327.

Kose, M. A., Prasad, E. S., and Terrones, M. E. (2006). How Do Trade and Financial Integration Affect The Relationship Between Growth and Volatility?. Journal of International Economics, 69: 176- 202.

Kose, M. A., Prasad, E. S., and Terrones, M. E. (2003). Financial Integration and Macroeconomic Volatility. IMF Working Paper, WP/03/50.

Kose, M. A., and Riezman, R. (1999). Trade Shocks and Macroeconomic Fluctuations in Africa. CSGR Working Paper, 43.

Lane, P. R., and Milesi-Ferretti, G. M. (2007). The External Wealth of Nations Mark II: Revised and Extended Estimates of Foreign Assets and Liabilities, 1970-2004. Journal of International Economics, 73: 223250.

Loayza, N. V., Rancie 'Re, R., Serve'N, L., and Ventura, J. (2007). Macroeconomic Volatility and Welfare in Developing Countries: An Introduction. The World Bank Economic Review, 21 (3): 343-357.

Prasad, E. S., and Rajan, R. G. (2008). A Pragmatic Approach to Capital Account Liberalization. The Journal of Economic Perspectives, 22 (3): 149-172.

Prasad, E. S., Rogoff, K., Wei, S-J., and Kose, M. A. (2007). Financial Globalization, Growth, and Volatility in Developing Countries. Globalization and Poverty: 457-516, Ed.: Harrison, A., University of Chicago Press.

Raddatz, C. (2007). Are External Shocks Responsible for The Instability of Output in Low-Income Countries?. Journal of Development Economics, 84: 155-187.

Reinhart, C.M., and Tokatlidis, I. (2003). Financial Liberalization: The African Experience. Journal of African Economies, 12 (1): 53-88.

Rodríguez, F., and Rodrik, D. (2001). Trade Policy and Economic Growth: A Skeptic's Guide to The CrossNational Evidence. NBER Macroeconomics Annual 2001, 15: 261-338. Eds.: Bernanke, B. S., and Rogoff, K., Cambridge, MA, MIT Press.

Roodman, D. (2009) How to Do Xtabond2: An Introduction to Difference and System GMM in Stata. Stata Journal, 9 (1): 86-136.

Sissoko, Y., and Dibooglu, S. (2006). The Exchange Rate System and Macroeconomic fluctuations in SubSaharan Africa. Economic Systems, 30 (2): 141-156.

Wacziarg, R., and Welch, K. H. (2008). Trade Liberalization and Growth: New Evidence. The World Bank Economic Review, 22 (2): 187-231. 


\section{Appendices}

\section{Appendix I: List of Countries}

Benin, Botswana, Burundi, Cameroon, Chad, Congo, Dem. Rep., Congo, Rep., Cote d'Ivoire, Ethiopia, Gabon, Gambia The, Ghana, Kenya, Madagascar, Malawi, Mali, Mauritania, Mauritius, Mozambique, Niger, Nigeria, Senegal, Sierra Leone, South Africa, Swaziland, Tanzania, Togo, Uganda, and Zambia.

\section{Appendix II: Data Sources and Definitions of Variables}

\begin{tabular}{|c|c|c|}
\hline Variables & Definition & Source and Construction \\
\hline GDP Volatility & $\begin{array}{l}\text { Standard deviation of the log } \\
\text { difference of GDP (constant } \\
2005 \text { US\$) }\end{array}$ & $\begin{array}{l}\text { Author's calculation using WDI, World Bank, } \\
\text { and Penn World Table, version 8.1 (RGDPE for } \\
\text { few missing GDP) }\end{array}$ \\
\hline Growth Volatility & $\begin{array}{l}\text { Standard deviation of the log } \\
\text { difference of per capita GDP } \\
\text { (constant 2005 US\$) }\end{array}$ & $\begin{array}{l}\text { Author's calculation using WDI, World Bank, } \\
\text { and Penn World Table, version 8.1 (RGDPE for } \\
\text { few missing per capita GDP) }\end{array}$ \\
\hline Per Capita GDP & $\begin{array}{l}\text { Log of GDP per capita } \\
\text { (constant } 2005 \text { US\$) }\end{array}$ & WDI, World Bank \\
\hline Trade Flows & Trade (\% of GDP) in logs & WDI, World Bank \\
\hline Natural Disaster & $\begin{array}{l}\text { The proportion of the } \\
\text { population affected (out of } \\
\text { total population) by natural } \\
\text { disaster in a given year. }\end{array}$ & EM-DAT, The International Disaster Database \\
\hline Financial Development & $\begin{array}{l}\text { Domestic credit to private } \\
\text { sector (\% of GDP) in logs }\end{array}$ & WDI, World Bank \\
\hline Financial Flows & $\begin{array}{l}\text { The sum of the stock of } \\
\text { portfolio equity and FDI } \\
\text { assets and liabilities to GDP } \\
\text { ratio. }\end{array}$ & $\begin{array}{l}\text { 'Updated and extended version of dataset } \\
\text { constructed by Lane and Milesi-Ferretti } \\
\text { (2007)'. We used current GDP from the same } \\
\text { source to calculate ratios. }\end{array}$ \\
\hline Terms of Trade Volatility & $\begin{array}{l}\text { Standard deviation of terms } \\
\text { of trade rate which is the log } \\
\text { difference of net barter terms } \\
\text { of trade index }\end{array}$ & Author's calculation using WDI, World Bank \\
\hline Inflation Volatility & $\begin{array}{l}\text { Standard deviation of the log } \\
\text { difference of consumer price } \\
\text { index }\end{array}$ & Author's calculation using WDI, World Bank \\
\hline Fiscal Policy Volatility & $\begin{array}{l}\text { The standard deviation of } \\
\text { discretionary fiscal policy }\end{array}$ & $\begin{array}{l}\text { Author's construction using Fatas and Mihov } \\
\text { (2003) method. This method regresses real } \\
\text { government expenditure }\left(G_{t}\right) \text { on real national } \\
\text { income }(Y) \text {, lag of government consumption } \\
\left(G_{t-1}\right) \text {, time trend }(\theta) \text {, inflation level }(\pi) \text { and its } \\
\text { square }\left(\pi^{2}\right) \text { as follows: } \\
\Delta G_{t}=\alpha+\theta_{t}+\beta_{1} \Delta Y_{t}+\beta_{2} \Delta G_{t-1}+\lambda_{1} \pi_{t}+\lambda_{2} \pi^{2}{ }_{t}+\varepsilon_{t} \\
\text { The standard deviation of the residual, } \varepsilon_{t} \text {, } \\
\text { obtained from this regression is used as a } \\
\text { measure of discretionary fiscal policy volatility. }\end{array}$ \\
\hline
\end{tabular}




\begin{tabular}{|l|l|l|}
\hline Portfolio Flows & $\begin{array}{l}\text { The stock of portfolio equity } \\
\text { assets and liabilities to GDP } \\
\text { ratio }\end{array}$ & $\begin{array}{l}\text { 'Updated and extended version of dataset } \\
\text { constructed by Lane and Milesi-Ferretti (2007)' }\end{array}$ \\
\hline FDI Flows & $\begin{array}{l}\text { The stock of FDI assets and } \\
\text { liabilities to GDP ratio }\end{array}$ & $\begin{array}{l}\text { 'Updated and extended version of dataset } \\
\text { constructed by Lane and Milesi-Ferretti (2007)' }\end{array}$ \\
\hline Trade in Manufacturing & $\begin{array}{l}\text { Trade in 'manufacturing } \\
\text { goods' as a percent of GDP } \\
\text { in log }\end{array}$ & $\begin{array}{l}\text { Author's calculation using WDI, World } \\
\text { Bank. We used Manufactures exports (\% of } \\
\text { merchandise exports), Manufactures imports } \\
\text { (\% of merchandise imports), Merchandise } \\
\text { exports (current US\$), Merchandise imports } \\
\text { (current US\$) and GDP (current US\$) data for } \\
\text { construction. }\end{array}$ \\
\hline $\begin{array}{l}\text { Trade in Non- } \\
\text { manufacturing }\end{array}$ & $\begin{array}{l}\text { 'Trade in non-manufacturing' } \\
\text { as a percent of GDP in log }\end{array}$ & $\begin{array}{l}\text { Author's calculation using WDI, World Bank. } \\
\text { We used similar data with the above for the } \\
\text { construction. }\end{array}$ \\
\hline Trade Liberalization & $\begin{array}{l}\text { A binary value which takes } \\
\text { zero and one before and } \\
\text { after the liberalization date } \\
\text { respectively for each country }\end{array}$ & $\begin{array}{l}\text { Wacziarg and Welch (2008)'s 'Year } \\
\text { Uninterrupted Openness Began'. We follow } \\
\text { Kassim (2013) to consider missing and recent } \\
\text { dates of liberalization. }\end{array}$ \\
\hline Financial Liberalization & $\begin{array}{l}\text { A binary value is assigned } \\
\text { similar with trade } \\
\text { liberalization. }\end{array}$ & $\begin{array}{l}\text { Reinhart and Tokatlidis (2003)'s measurement, } \\
\text { which is based on comprehensive assessment } \\
\text { and shows the switching year towards a more } \\
\text { external financial liberalization. }\end{array}$ \\
\hline
\end{tabular}

